\title{
Effects of both ecdysone and the acclimation to low temperature, on growth and metabolic rate of juvenile freshwater crayfish Cherax quadricarinatus (Decapoda, Parastacidae)
}

\author{
Anouk Chaulet ${ }^{1}$, Itzick Vatnick ${ }^{2} \&$ Enrique M. Rodríguez $^{1}$
}

\footnotetext{
1. Department of Biodiversity and Experimental Biology - IBBEA-CONICET. FCEyN - University of Buenos Aires. Ciudad Universitaria, Pab. II. C1428EHA. Buenos Aires, Argentina. (enrique@bg.fcen.uba.ar)

2. Department of Biology, Widener University, Chester, PA 19809 USA
}

\begin{abstract}
Growth, metabolic rate, and energy reserves of Cherax quadricarinatus (von Martens, 1868) juveniles were evaluated in crayfish acclimated for 16 weeks to either $25^{\circ} \mathrm{C}$ (temperature near optimum) or $20^{\circ} \mathrm{C}$ (marginal for the species). Additionally, the modulating effect of ecdsyone on acclimation was studied. After 12 weeks of exposure, weight gain of both experimental groups acclimated to $25^{\circ} \mathrm{C}$ (control: $\mathrm{C} 25$, and ecdysone treated: E25) was significantly higher than that of those groups acclimated to $20^{\circ} \mathrm{C}(\mathrm{C} 20$ and E20). A total compensation in metabolic rate was seen after acclimation from $25^{\circ} \mathrm{C}$ to $20^{\circ} \mathrm{C}$; for both the control group and the group treated with ecdysone. A $\mathrm{Q}_{10}$ value significantly higher was only observed in the group acclimated to $20^{\circ} \mathrm{C}$ and treated with ecdysone. A reduction of glycogen reserves in both hepatopancreas and muscle, as well as a lower protein content in muscle, was seen in both groups acclimated to $20^{\circ} \mathrm{C}$. Correspondingly, glycemia was always higher in these groups. Increased lipid levels were seen in the hepatopancreas of animals acclimated to $20^{\circ} \mathrm{C}$, while a higher lipid level was also observed in muscle at $20^{\circ} \mathrm{C}$, but only in ecdysone-treated crayfish.
\end{abstract}

KEYWORDS. Energy reserves, growth, metabolic rate, $\mathrm{Q}_{10}$.

RESUMEN. Efectos de ecdisona y de la aclimatación a baja temperatura, sobre el crecimiento y la tasa metabólica de juveniles de la langosta de agua dulce Cherax quadricarinatus (Decapoda, Parastacidae). Se evaluaron las reservas energéticas, el crecimiento y la tasa metabólica de langostas juveniles de agua dulce Cherax quadricarinatus (von Martens, 1868), aclimatadas durante 16 semanas tanto a $25^{\circ} \mathrm{C}$ (temperatura cercana al óptimo) como a $20^{\circ} \mathrm{C}$ (temperatura marginal para la especie). Adicionalmente, se evaluó el efecto modulador de la ecdisona sobre la aclimatación. Luego de 12 semanas de exposición, la ganancia en peso de ambos grupos experimentales aclimatados a $25^{\circ} \mathrm{C}$ (control: C25, y tratados con ecdisona: E25) fue significativamente mayor que la de los grupos aclimatados a $20^{\circ} \mathrm{C}(\mathrm{C} 20$ and E20). Se verificó una compensación total en la tasa metabólica, luego de la aclimatación desde 25 a $20^{\circ} \mathrm{C}$, tanto para el grupo control como para el tratado con ecdisona. Solamente se observó un valor de $\mathrm{Q}_{10}$ significativamente mayor en el grupo aclimatado a $20^{\circ} \mathrm{C}$ y tratado con ecdisona. En ambos grupos aclimatados a $20^{\circ} \mathrm{C}$, se determinó un reducción en la reservas de glucógeno, tanto en hepatopancreas como en músculo, así como un menor contenido de proteína en músculo. Correspondiente, la glucemia resultó siempre más elevada en esos grupos, que también mostraron un mayor nivel de lípidos en el hepatopancreas, siendo mayor el nivel de lípidos en músculo sólo para los juveniles aclimatados a $20^{\circ} \mathrm{C}$ y tratados con ecdisona.

PALABRAS-CLAVE. Reservas energéticas, crecimiento, tasa metabólica, $\mathrm{Q}_{10}$.

Metabolic rate of invertebrates depends on several intrinsic and extrinsic factors. Intrinsic factors include: age, gender, weight, degree of locomotor activity and internal work. Extrinsic factors include: ambient temperature, photoperiod, impact of stressors and food availability. Temperature clearly exerts a major influence on metabolic rate of poikilothermic species. However, most poikilotherms display compensatory mechanisms against temperature change; several species are even capable of full compensation and hold their metabolic rate at the same level they had at a higher temperature after an acclimation period to the new lower temperature (HiLl et al., 2004). This process, known as metabolic compensation, allows poikilothermic species to minimize the effects of ambient temperatures on physiological processes and to maintain their level of activity at low temperatures (LAGERSPETZ, 2006). The $\mathrm{Q}_{10}$ is the factor by which a reaction rate is increased by an increase of ambient temperature by $10^{\circ} \mathrm{C}$ reflecting the relationship of physiological processes such as metabolic rate, to acute temperature changes. The $\mathrm{Q}_{10}$ of metabolic rate of poikilotherms varies at different ambient temperatures; however, it usually has a value of 2-3 (HILl et al., 2004).
Cherax quadricarinatus (von Martens, 1868) is a parastacid crayfish species that inhabits rivers, and ponds of Queensland and other subtropical region of Australia (JONES, 1997). Seasonal fluctuations in temperature and water level stimulate their migration against water current, and therefore they are likely to reach more stable environments (JoNes, 1997; MEADE et al., 2002). Populations of C. quadricarinatus are commonly found in water bodies highly oxygenated and with rich vegetation. Lower and upper lethal temperatures were reported as $10^{\circ} \mathrm{C}$ and $36^{\circ} \mathrm{C}$, respectively, while growth is optimum between $25^{\circ} \mathrm{C}$ and $30^{\circ} \mathrm{C}$; this species is also tolerant to a wide salinity range (Meade et al., 2002). However, not much is known regarding the thermal acclimation capacity of $C$. quadricarinatus or the physiological responses involved in this acclimation. This knowledge would be relevant for improving the culturing of this species in temperate climates. In Argentina, the production of this species has increased during the last decade in areas where the climate is marginal for culturing; therefore, developing compensatory management techniques is certainly needed especially for juveniles. 
Molting of crustaceans is controlled by ecdsysone, secreted as $\alpha$-ecdsysone from the Y-organ. This hormone is further transformed to 20-hydroxyecdisone (or $\beta$-ecdysone) in peripheral tissues (CHANG, 1995). 20-hydroxyecdysone peaks during mid- premolt, to return to basal levels in the postmolt and intermolt periods (Lachaise et al., 1993; Chang \& Mykles, 2011). Although some anabolic effects of ecdysone have been reported in crustaceans (such as stimulation of vitelogenin synthesis, GunAmalai et al., 2004) and mammals (increase of protein synthesis in several tissues, Le Bizec et al., 2002), no physiological role of this hormone on the thermal acclimation of crustaceans have been previously reported.

This study was aimed to assess the effects of acclimation to a temperature lower than the optimum on: metabolic rate, the utilization of energy reserves, and growth rate of C. quadricarinatus juveniles. Additionally, the effect of ecdysone administration on these processes was also studied. We hypothesized that juveniles acclimated to a sub-optimum temperature will be able to compensate their metabolic rate, being facilitated this process by ecdysone.

\section{MATERIAL AND METHODS}

Juvenile crayfish used for the acclimation experiment had a mean body weight $0.93 \pm 0.02 \mathrm{~g}$ $(\mathrm{N}=48)$; they hatched in the laboratory from females purchased at a local farm (Pinzas Rojas SRL, Tucumán, Argentina) at a body weight averaging $0.01 \mathrm{~g}$. During the growing period from hatching to the selected weight, all animals were maintained in glass aquaria with dechlorinated tap water (hardness $=80 \mathrm{mg} / \mathrm{L}$ as $\mathrm{CaCO}_{3}$ equivalents, $\mathrm{pH}=7.8$ ), with small PVC pipes as refuges and continuous aeration. The aquaria were housed in a room with a photoperiod of 14:10 (L:D) and a temperature of $27 \pm 1^{\circ} \mathrm{C}$ throughout the experiment. During this growing period, crayfish were fed ad libitum with commercial fish food and fresh leaves of Elodea sp. and the water in the aquaria was changed twice a week.

For the acclimation experiment, each juvenile was placed in a glass container filled with $400 \mathrm{~mL}$ of dechlorinated and filtered tap water, provided with a small PVC pipe as a refuge. The water source and water replacement frequency were the same as in the growing period. Levels of ammonia, nitrite, alkalinity and hardness, were measured both before and after changing water. Ammonia was determined by means of a colorimetric method (Wiener kit), after hydrolysis with urease. Colorimetric kits were used to assess the rest of the variables. The water quality including the levels of ammonia, nitrite, alkalinity, hardness, and $\mathrm{pH}$ remained within the acceptable limits for the studied species (BOYD, 1982; JONES, 1997) throughout the experiment.

The experiment started at mid-summer and lasted 16 weeks. Twelve animals were assigned to each of the following experimental groups: (i) C20: acclimated to $20^{\circ} \mathrm{C}$ and fed with standard diet; (ii) $\mathrm{C} 25$ : acclimated to $25^{\circ} \mathrm{C}$ and fed with standard diet; (iii) E20: acclimated to $20^{\circ} \mathrm{C}$ and fed with a diet supplemented with ecdysone; (iv) E25: acclimated to $25^{\circ} \mathrm{C}$ and fed with a diet supplemented with ecdysone.

Both groups acclimated to $20^{\circ} \mathrm{C}$ were maintained in a temperature controlled incubator, with regulated light cycles and air exchange. Those groups acclimated to $25^{\circ} \mathrm{C}$ were maintained in a room provided with air conditioning. A photoperiod of 14:10 (L:D) was maintained in all groups. Control groups (C20 and C25) were fed daily a standard diet of commercial fish food at 3\% of biomass. Once a week, fresh leaves of Elodea sp. were also given. The remaining experimental groups were fed in the same way, but three times a week the same standard diet was enriched with ecdysone, in a dose formulated to administer in one pellet $10^{-10} \mathrm{~mol}$ of ecdysone/g of crayfish, according to previous studies on the same species (CHAUlet et al., 2008). Only after the enriched pellet was totally consumed, the remaining pellets were offered. Enriched pellets were prepared by adding $\alpha$-ecdysone dissolved in ethanol to the standard diet, which was then re-pelleted and dried at $37^{\circ} \mathrm{C}$.

All animals were weighed every two weeks, in order to adjust the food ration and also to calculate the weight gain $(\mathrm{WG})$ as $\mathrm{WG}=\left(\left(\mathrm{W}_{\mathrm{x}}-\mathrm{W}_{\mathrm{i}}\right) / \mathrm{W}_{\mathrm{i}}\right) \times 100$, where $\mathrm{W}_{\mathrm{x}}$ is the body weight measured every two weeks, from the beginning of the experiment, and $\mathrm{W}_{\mathrm{i}}$ is the initial fresh body weight. Molting and mortality were recorded daily. The degree of locomotion was also qualitatively monitored in all the experimental groups.

At the end of the assay, the specific metabolic rate was estimated as the rate of oxygen consumption per gram (wet weight basis), by means of a constant volume flow-through respirometer. The metabolic chamber was constructed from a hermetically sealed glass jar stoppered with a rubber stopper fitted with a dissolved oxygen probe and connected to a peristaltic pump, by means of plastic connectors. Each animal was initially placed in the chamber and left 10 minutes to allow a resting condition, before recording the oxygen concentration dissolved in water during 20 minutes, at a constant temperature of $25^{\circ} \mathrm{C}$ or $20^{\circ} \mathrm{C}$. Sensor information was digitalized and recorded on a computer. The data obtained were stored for later analysis by linear regression; the absolute value of the slope was the oxygen consumption rate, finally expressed as $\mu \mathrm{g} / \mathrm{min} / \mathrm{g}$. Animals were not fed during the $48 \mathrm{~h}$ previous to each recording and each animal was measured first at the temperature at which it had been acclimated, and followed immediately by a second measurement at the remaining temperature. $\mathrm{Q}_{10}$ was

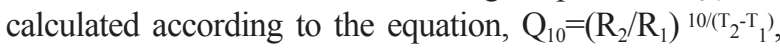
where $R_{x}$ is the metabolic rate corresponding to each of the two temperatures of measurement $\left(\mathrm{T}_{2}=25^{\circ} \mathrm{C}, \mathrm{T}_{1}=20^{\circ} \mathrm{C}\right)$.

At the end of the experiment animals were chilled in an ice-water bath, sacrificed and dissected. Both the hepatopancreas and abdominal muscle were quickly 
extracted and frozen at $-70^{\circ} \mathrm{C}$ until analysis together with hemolymph samples. Glycogen was extracted by the VAN HANDEL (1965) method and free glucose content was estimated with a colorimetric kit (glucose oxidase method) after acid hydrolysis with $\mathrm{HCl}$, followed by neutralization with $\mathrm{Na}_{2} \mathrm{CO}_{3}$. Total protein content was quantified according to LowRY et al. (1951) using bovine albumin as a standard. Total lipids were extracted by the method of FoLCH et al. (1957) and quantified by the method of FrINGS et al. (1970).

A three way ANOVA (acclimation temperature and hormonal treatment as independent factors, and temperature of measurement as repeated measurement factor), followed by planned comparisons (SoKaL \& RoHLF, 1981), were used to compare the experimental oxygen consumption, $\mathrm{Q}_{10}$, and energy reserves. Data normality and homogeneity of variances were always confirmed. Fisher exact test (SoKal \& RoHLF, 1981) was used to compare proportions (mortality and molting) among treatments. A 5\% confidence level was considered in all cases.

\section{RESULTS}

Mortality during the experiment ranged from $0 \%$, in the $\mathrm{C} 20$ group, to a maximum of $25 \%$ in the E25 group; no significant ( $>00.05)$ difference was detected among groups (Tab. I). The only statistically significant difference in molting was observed for the second molting. The frequency of molting of the E-20 was higher $(p<0.05)$ than that of $\mathrm{C} 20$. The degree of activity, in terms of locomotion, was similar in all the experimental groups.

Figure 1 shows the WG for the four experimental groups during the 16 weeks of the experiment. At the sixth week, WG of the C25 group begins to be significantly $(p<0.05)$ higher than that of both groups acclimated to $20^{\circ} \mathrm{C}$, while just after the twelfth week the E25 group differ significantly $(\mathrm{p}<0.05)$ from the remaining two groups acclimated to $20^{\circ} \mathrm{C}$. In these groups, some quantity of food usually remained uneaten at the end of feeding, while this was not observed for both groups acclimated to $25^{\circ} \mathrm{C}$. However, the ecdysoneenriched pellet initially offered was always eaten, at both acclimation temperatures.

Figure 2 shows the metabolic rate (oxygen

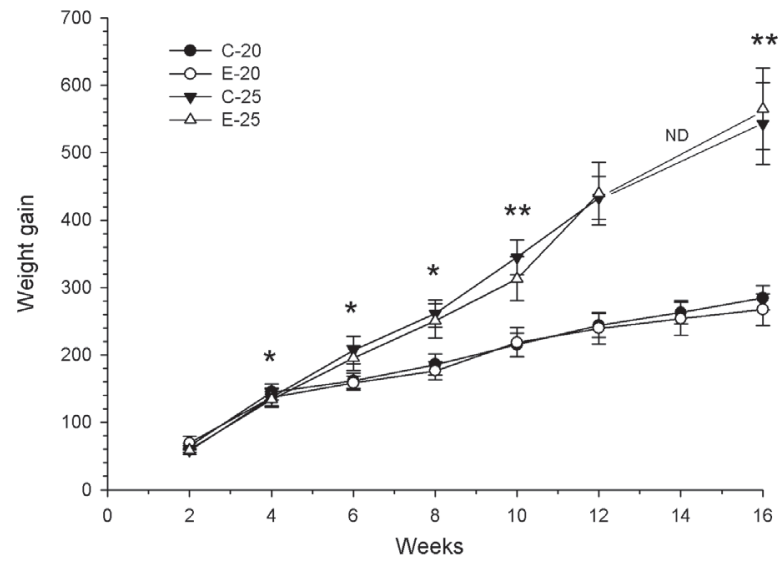

Fig. 1. Weight gain (mean \pm standard error) of Cherax quadricarinatus (von Martens, 1868) juveniles C: control and E: ecdysone treated groups, acclimated to either 20 or $25^{\circ} \mathrm{C} \mathrm{[*}$, indicates significant differences $(p<0.05)$ between $\mathrm{C}-25$ and both groups acclimated to $20^{\circ} \mathrm{C}$; **, asterisk indicates significant differences $(\mathrm{p}<0.05)$ between both groups acclimated to $25^{\circ} \mathrm{C}$ and both groups acclimated to $20^{\circ} \mathrm{C}$; $\mathrm{ND}$, not determined].

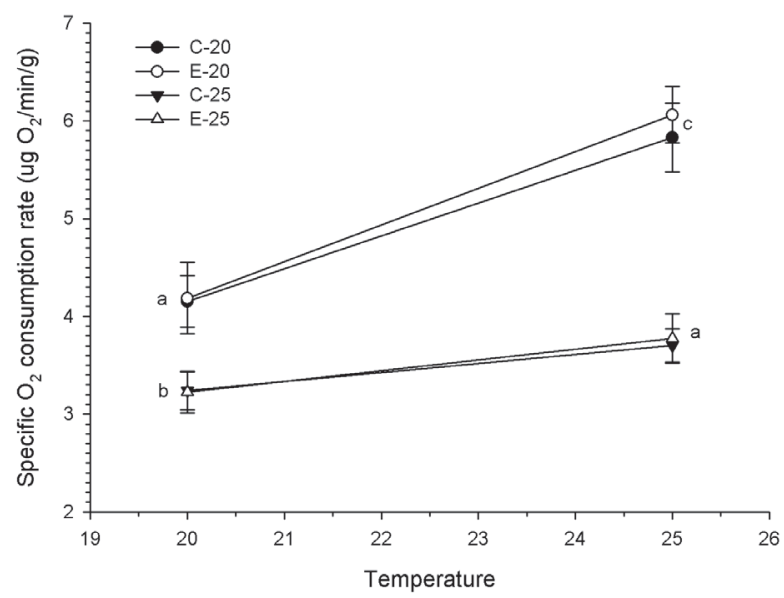

Fig. 2. Oxygen consumption rate ( $\mu \mathrm{g} \mathrm{O}_{2} / \mathrm{min} / \mathrm{g}$ ) of Cherax quadricarinatus (von Martens, 1868) juveniles, measured at the end of the assay. $\mathrm{C}$ : control and E: ecdysone treated groups, acclimated to either 20 or $25^{\circ} \mathrm{C}$. Different letters indicate significant differences $(\mathrm{p}<0.05)$. No difference $(p>0.05)$ between any control and ecdysone-treated group was seen at the same temperature of acclimation and measurement.

consumption rate) at the end of the experiment. For each one of the four experimental groups, the metabolic rate measured at $25^{\circ} \mathrm{C}$ was significantly $(\mathrm{p}<0.05)$ higher than that measured at $20^{\circ} \mathrm{C}$. At any temperature of measurement, both groups acclimated to $20^{\circ} \mathrm{C}$ had a metabolic rate significantly $(p<0.05)$ higher than that of

Tab. I. Mortality and molting of Cherax quadricarinatus (von Martens, 1868) juveniles. Number of molted (M) over the alive (A) crayfish at every molting event is indicated. Initial number of animals $=12$ in all groups. [*, significantly $(\mathrm{p}<0.05)$ higher percentage than control; $\mathrm{C}$, control; $\mathrm{E}$, ecdysone treated groups, acclimated to either 20 or $\left.25^{\circ} \mathrm{C}\right]$.

\begin{tabular}{|c|c|c|c|c|c|c|c|c|c|c|c|c|c|}
\hline \multirow[t]{2}{*}{ Group } & \multicolumn{2}{|c|}{ 1st molt } & \multicolumn{2}{|c|}{ 2nd molt } & \multicolumn{2}{|c|}{ 3rd molt } & \multicolumn{2}{|c|}{ 4th molt } & \multicolumn{2}{|c|}{5 th molt } & \multicolumn{2}{|c|}{6 th molt } & \multirow[t]{2}{*}{$\begin{array}{l}\text { Final } \mathrm{N} \text { of alive } \\
\text { crayfish }\end{array}$} \\
\hline & M & A & M & A & M & A & M & A & M & A & M & A & \\
\hline C-20 & 12 & 12 & 6 & 12 & 4 & 12 & 1 & 12 & 0 & 12 & 0 & 12 & 12 \\
\hline E-20 & 12 & 12 & $11^{*}$ & 11 & 3 & 10 & 0 & 10 & 0 & 10 & 0 & 10 & 10 \\
\hline C-25 & 11 & 12 & 8 & 10 & 3 & 10 & 2 & 10 & 1 & 10 & 0 & 10 & 10 \\
\hline E-25 & 11 & 12 & 9 & 11 & 5 & 9 & 1 & 9 & 1 & 9 & 1 & 9 & 9 \\
\hline
\end{tabular}


the groups acclimated to $25^{\circ} \mathrm{C}$. However, the metabolic rate of both groups acclimated to $20^{\circ} \mathrm{C}$ and measured at the same temperature, was similar $(\mathrm{p}>0.05)$ to the rate of the groups acclimated and measured at $25^{\circ} \mathrm{C}$. Although the metabolic rate (Fig. 2) and the $\mathrm{Q}_{10}$ (Fig. 3) of the control groups did not differ $(p>0.05)$ from that of ecdysone-treated group acclimated and measured at the same temperature, the $\mathrm{Q}_{10}$ of the E20 group was significantly $(p<0.05)$ higher than that of any group acclimated to $25^{\circ} \mathrm{C}$ (Fig. 3).

Levels of energy reserves are shown in Figures 4-6. Comparing the groups acclimated to $20^{\circ} \mathrm{C}$ with those acclimated to $25^{\circ} \mathrm{C}$, hemolymphatic glucose concentrations were significantly higher $(p<0.05)$ at $20^{\circ} \mathrm{C}$, while glycogen levels were significantly $(\mathrm{p}<0.05)$ lower, in both hepatopancreas and muscle (Fig. 4). No significant $(\mathrm{p}>0.05)$ differences were observed in the hepatopancreatic protein level among experimental groups, but protein content of both muscle and hemolymph was significantly $(\mathrm{p}<0.05)$ higher in both groups acclimated to $20^{\circ} \mathrm{C}$ than the groups acclimated to $25^{\circ} \mathrm{C}$ (Fig. 5). Lipid hemolymphatic level (Fig. 6), was significantly $(\mathrm{p}<0.05)$ higher in the $\mathrm{C} 25$ group with respect to the remaining groups. In the hepatopancreas, C20 showed a significantly $(\mathrm{p}<0.05)$ higher lipid level compared to both groups acclimated to $25^{\circ} \mathrm{C}$, while E20 showed an intermediate level. E20 showed the highest lipid level in muscle, significantly $(p<0.05)$ different from the remaining groups.

\section{DISCUSSION}

An augmented growth rate, both in terms of weight and size, was reported for the king crab Paralithodes camtschaticus (Tilesius, 1815) at high temperatures, within its thermal range of tolerance; in this species, as in many other crustaceans, a reduction in the intermolt period at higher temperatures was also observed (STONER et al., 2010). In the current study, molt frequency determined at the end of the experiment was similar at both acclimation temperatures. A higher molting percent was observed with ecdysone, but only in the second molt at $20^{\circ} \mathrm{C}$. At all other times no differences with control were noted. Since juveniles assigned to all experimental groups hatched synchronously in the laboratory and were maintained under the same conditions before starting the experiment, no effects on molting caused by factors other than those manipulated during the experiment were expected.

There are several homeostatic mechanism aimed at maintained the typical basal levels of ecdysone $(<20 \mathrm{ng} / \mathrm{ml})$ during postmolt and intermolt (ChANG \& Mykles, 2011). Among these mechanisms, the degradation of lypophilic hormones and other compounds by the microsomal cytochrome P450 enzymes, particularly relevant in the hepatopancreas, should be stressed. This inactivation involves the

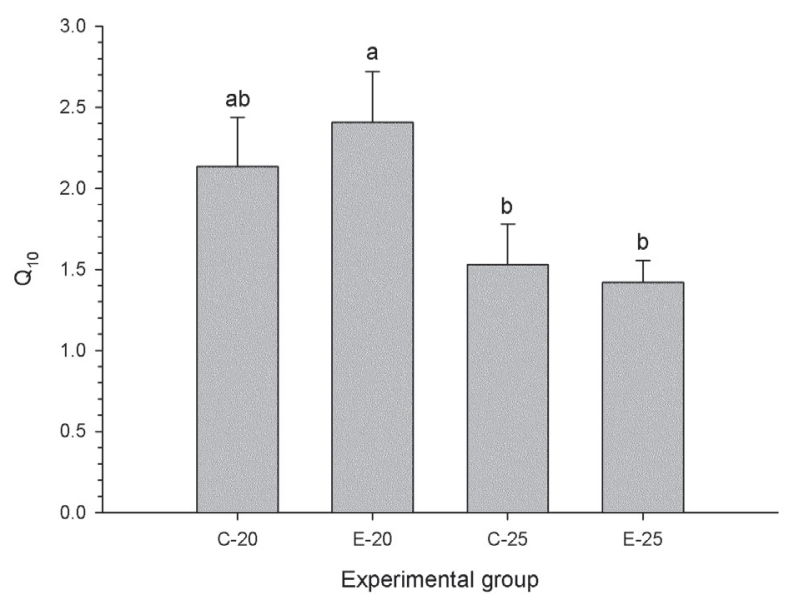

Fig. 3. $\mathrm{Q}_{10}$ values for oxygen consumption rate of Cherax quadricarinatus (von Martens, 1868) juveniles, at the end of the experiment. $\mathrm{C}$ : control and $\mathrm{E}$ : ecdysone treated groups, acclimated to either 20 or $25^{\circ} \mathrm{C}$. Different letter indicate significant differences $(\mathrm{p}<0.05)$.

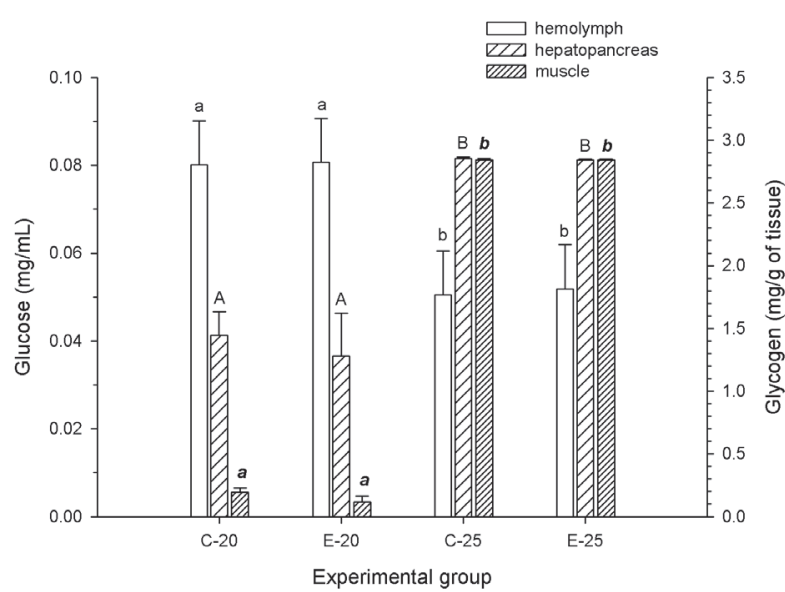

Fig. 4. Glucose hemolymplatic levels and glycogen content in hepatopancreas and muscle of Cherax quadricarinatus (von Martens, 1868) juveniles, at the end of the experiment. C: control and $\mathrm{E}$ : ecdysone treated groups, acclimated to either 20 or $25^{\circ} \mathrm{C}$. For each tissue, different letters indicate significant differences $(\mathrm{p}<0.05)$.

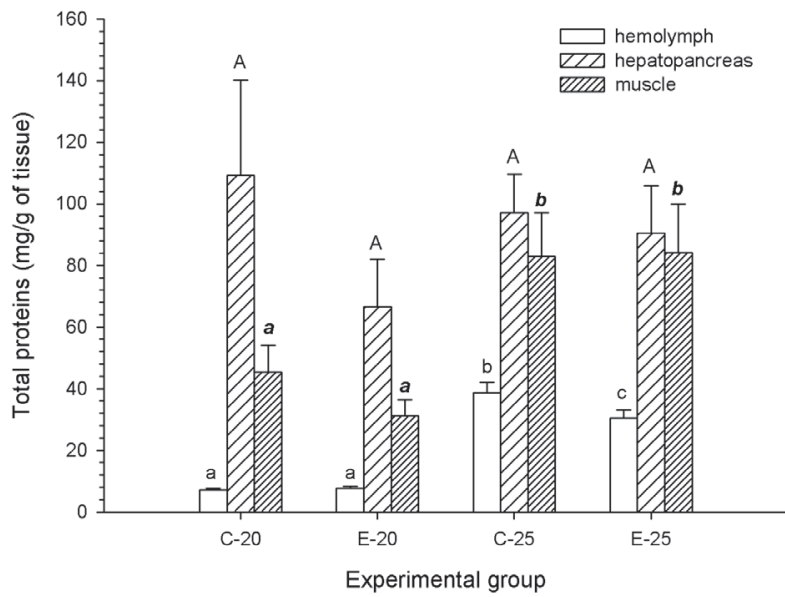

Fig. 5. Total protein content in hemolypmph, hepatopancreas and muscle of Cherax quadricarinatus (von Martens, 1868) juveniles, at the end of the experiment. C: control and E: ecdysone treated groups, acclimated to either 20 or $25^{\circ} \mathrm{C}$. For each tissue, different letters indicate significant differences $(\mathrm{p}<0.05)$. 


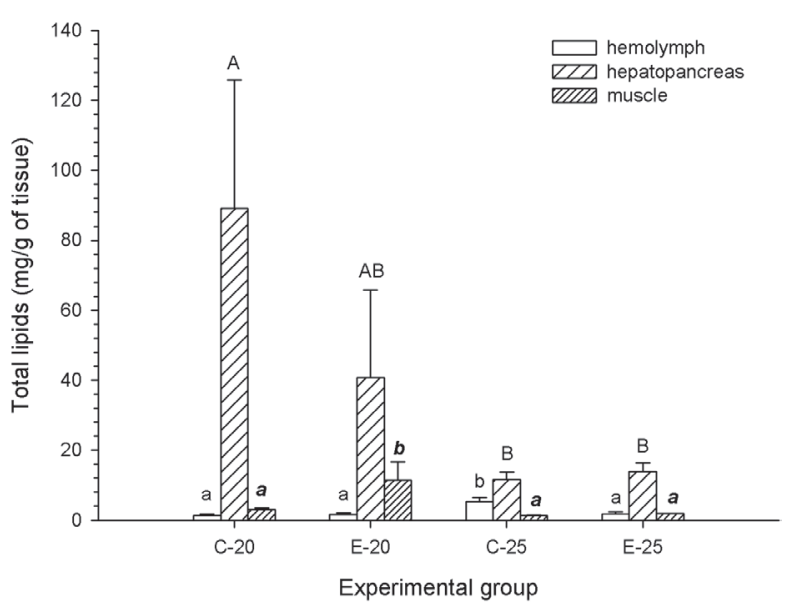

Fig. 6. Total lipid content in hemolypmph, hepatopancreas and muscle of Cherax quadricarinatus (von Martens, 1868) juveniles, at the end of the experiment. C: control and E: ecdysone treated groups, acclimated to either 20 or $25^{\circ} \mathrm{C}$. For each tissue, different letters indicate significant differences $(\mathrm{p}<0.05)$.

conversion of ecdysteroids to polar metabolites and/or conjugates, which are eliminated in the urine and feces. Moreover, the hepatopancreas appears to be central in sequestering ecdysteroids obtained from the diet to prevent disruption of ecdysteroid-regulated processes (MyKLES, 2011). Thus, our results mostly suggest that those homeostatic mechanisms seem to prevent any increase of ecdysone significant for molting, when this hormone is administered at low doses. In this sense, our experiment was very different to the administration of high dose-pulses of ecdysone, a methodology employed in several previous studies for inducing molting (reviewed by Chang \& MyKLes, 2011).

In this study, weight gain was reduced at $20^{\circ} \mathrm{C}$, in close correlation with the lower protein level in muscle and glycogen in both hepatopancreas and muscle of crayfish acclimated to $20^{\circ} \mathrm{C}$, compared to animals acclimated to $25^{\circ} \mathrm{C}$. Reduction in food consumption at $20^{\circ} \mathrm{C}$ could certainly be the primary cause of the lower growth, although juvenile crayfish were as active as those maintained at $25^{\circ} \mathrm{C}$. As discussed below, the metabolic rate compensation that took place during the acclimation process from 25 to $20^{\circ} \mathrm{C}$ would allow juveniles to maintain a similar degree of activity at any temperature, but such compensation did not seem to be enough to prevent a lower food intake at the lowest temperature assayed.

Ecdsyone did not augment growth at any temperature of acclimation, indicating an absence of an anabolic effect of this steroid on tissue buildup. In a previous study with $C$. quadricarinatus juveniles (Chaulet et al., 2008), addition of ecdysone to the diet augmented weight of early juveniles ( $20 \mathrm{mg}$ body mass), but this effect was not observed in advanced juveniles (1 g body mass), which were similar to the animals used in the current study. Additionally, ecdysone may induce mobilization and consumption of body reserves of animals acclimated to $25^{\circ} \mathrm{C}$ since the weight gain of E25 group was different from that of both groups acclimated to $20^{\circ} \mathrm{C}$ only after the twelfth weeks while $\mathrm{C} 25$ differed after the sixth week. Further supporting evidence for this effect, are the lower hemolymphatic levels of both protein and lipid showed by E25 as compared to C25.

In several crustacean species, a significant reduction in the oxygen consumption was observed after chronic exposure to relatively low temperatures (GonzÁLEZ et al., 2010). This metabolic depression was not the case for $C$. quadricarinatus juveniles acclimated to $20^{\circ} \mathrm{C}$ in this study. On the contrary, these juveniles showed a complete metabolic compensation (with a tendency to overcompensation), and therefore maintained the capacity to sustain the rate of other processes such as locomotion. Several other crustacean species have shown either a partial or a total metabolic compensation with chronic temperature changes, (PAUL et al., 2004; TIAN, 2004). Both groups acclimated to $20^{\circ} \mathrm{C}$ showed a higher increment in their metabolic rate after an acute change from 20 to $25^{\circ} \mathrm{C}$ (Fig. 3); however, only the E20 group $\mathrm{Q}_{10}$ value was significantly different $(\mathrm{p}<0.05)$ from both groups acclimated to $25^{\circ} \mathrm{C}$ (Fig. 4). This apparent effect of ecdysone in increasing metabolic response to acute temperature changes in animals chronically acclimated to cold temperatures needs further confirmation, though.

A significant lower specific content of glycogen, in both hepatopancreas and muscle, as well as a lower protein content in muscle, was clearly seen in both groups acclimated to $20^{\circ} \mathrm{C}$ compared to those acclimated to $25^{\circ} \mathrm{C}$. These results were in close correlation with the higher glycemia observed at $20^{\circ} \mathrm{C}$, probably needed to sustain the relatively high metabolic rate observed at that temperature. Glycogen can be directly used to augment the glucose in hemolymph, while proteins can be used for the same purpose after gluconeogenesis. In fact, the crustacean hepatopancreas is able to carry out gluconeogenesis from muscle protein as substrate, to elevate glycemia to support a higher metabolic demand (MARTINs et al., 2011). An early utilization of glycogen has been reported in the white shrimp, Litopenaeus vannamei, acclimated from 28 to $13^{\circ} \mathrm{C}$; additionally, a further utilization of proteins take place in the same species at longer acclimation time (ZHOU et al., 2011). Several crustaceans mobilize protein under stressful situations such as starvation (SÁNCHEZ PAZ et al., 2006). In C. quadricarinatus, both protein and lipids have been identified as the main energy reserves for either growth or reproduction (GHANAwI \& SAOUD, 2012).

Despite of the glycogen and protein utilization, lipid reserves were clearly augmented in the hepatopancreas of juveniles acclimated to $20^{\circ} \mathrm{C}$, although ecdsysone promoted their utilization to some degree. Hepatopancreatic lipid levels in several crustacean species are higher in winter than in summer, probably as a strategy to increase energy reserves to face the unfavorable conditions of winter (LUVIzOTTO 
et al., 2003). The utilization of lipids as energy reserve has been also reported under situations such as a long starvation (VINAGRE \& DA SiLva, 1992). Lipid reserves are typically used for ovarian growth during the prereproductive period (ABDU et al., 2000). Estuarial crabs Neohelice granulata (Dana, 1851) used lipids during ionic hyporegulation, but during hyperegulation lipid reserves remained unaltered (LuvizotTo SANTOS et al., 2003). In the same species exposed to high salinities, higher lipid storage from free amino acids was seen both in hepatopancreas and muscle, in relation to the needs for osmotic regulation (MARTINs et al., 2011).

Ecdysone increased lipid storage in muscle, in crayfish acclimated to $20^{\circ} \mathrm{C}$. During premolt, the storage of lipids in the hepatopancreas commonly take place, in correlation with the increase concentration of ecdsyone (CHANG, 1995), but no causal relationship between both variables has been clearly demonstrated. In fact, BolLENBACHER et al. (1972) reported no effect on the rate of lipid synthesis in the hepatopancreas of premolt crabs, when either the Y-organ was removed or ecdysone was injected. In the same tissue, an attenuation of lipases transcription by effect of ecdysone was reported (YUDKOSKI et al., 2007). In crustacean muscle, an increment of membrane fluidity at lower temperatures was observed, and during the Spring the phospholipid content was higher in coldacclimated marine crabs than in warm-acclimated animals (CUCULESCU et al., 1995).

We conclude that, although juvenile of the studied species acclimated to a relatively low temperature grew at a lower rate than those acclimated to an optimal temperature, they were able to reach a total metabolic compensation, enough for maintaining a normal activity. To some extent, ecdysone was able to support such compensation.

Acknowledgments. This study was supported by grants from CONICET (PIP 0884) and UBACYT 2011-2014 / 2012-2015 programs.

\section{REFERENCES}

Abdu, U.; Yehezkel, G. \& SAGi, A. 2000. Oocyte development and polypeptide dynamics during ovarian maturation in the red-claw crayfish Cherax quadricarinatus. Invertebrate Reproduction and Development 37:75-83

Bollenbacher, W. E.; Flechner, S. M. \& O'Connor, J. D. 1972. Regulation of lipid synthesis during early premolt in decapod crustaceans. Comparative Biochemistry and Physiology 42B: $157-158$.

Boyd, C. E. 1982. Water quality Management of Pond Fish Culture. Amsterdam, Elsevier Scientific Publishing Company. $318 \mathrm{p}$.

Chang, E. S. 1995. Physiological and biochemical changes during the molt cycle in decapod crustaceans: an overview. Journal of Experimental Marine Biology and Ecology 193:1-14.

ChANG, E. S. \& MykLes, D. L. 2011. Regulation of crustacean molting: A review and our perspectives. General Comparative and Endocrinology 172:323-330.

Chaulet, A.; López Greco, L. S. \& Rodríguez, E. M. 2008. Somatic growth of juvenile freshwater crayfish Cherax quadricarinatus, by ecdysone added to different diets. In: Possebon Cyrino, J. E ; Scorvo Filho, J. D. \& Sampaio, L. A. eds. Tópicos especiais em biologia aquática e aqüicultura II. São Paulo, Sociedade Brasileira de Aqüicultura e Biologia Aquática. p.305-313.

Cuculescu, M.; Hyde, D. \& Bowler, K. 1995. Temperature acclimation of marine crabs: changes in plasma membrane fluidity and lipid composition. Journal of Thermal Biology 20:207-222

Folch, J.; Lees, M. \& Stanley, G. H. S. 1957. A simple method for isolation and purification of total lipids from animal tissues. Journal of Biological Chemistry 226:497-509.

FringS, C. S. \& DunN, R. T. 1970. A colorimetric method for determination of total serum lipids based on the sulfophosphovanilin reaction. American Journal of Clinical Pathology 53:89-91.

Ghanawi, J. \& SAOUd, I. P. 2012. Molting, reproductive biology, and hatchery management of redclaw crayfish Cherax quadricarinatus (von Martens, 1868). Aquaculture 358-359:183-195.

González, R. A.; Díaz, F.; Licea, A.; Re, A. D.; SÁnchez, L. N. \& GarcíA-Esquivel, Z. 2010. Thermal preference, tolerance and oxygen consumption of adult white shrimp Litopenaeus vannamei (Boone) exposed to different acclimation temperatures. Journal of Thermal Biology 35:218-224.

Gunamalai, V.; Kirubagaran, R. \& Subramoniam, T. 2004. Hormonal coordination of molting and female reproduction by ecdysteroids in the mole crab Emerita asiatica Milne Edwards. General and Comparative Endocrinology 138:128-138.

Hill, R. W.; Wyse, G. A. \& Anderson, M. 2004. Animal Physiology. Massachusetts, Sinauer Associates. 770p.

JoNES, C. M. 1997. The biology and aquaculture potencial of the tropical freshwater crayfish Cherax quadricarinatus. Brisbane, Queensland Department of Primary Industries. 109p.

Lachaise, F.; Le Roux, A.; Hubert, M. \& Lafont, R. 1993. The molting gland of crustaceans: localization, activity, and endocrine control. Journal of Crustacean Biology 13:198-234.

LAGERSPETZ, K. Y. H. 2006. What is thermal acclimation? Journal of Thermal Biology 31:332-336.

Le Bizec, B.; Antignac, J. P.; Monteau, F. \& Andre, F. 2002. Ecdysteroids: one potential new anabolic family in breeding animals. Analytical Chimica Acta 473:89-97.

Lowry, O. H.; Rosenbrough, N. J. \& Randall, R. J. 1951. Protein measurements with the Folin phenol reagent. Journal of Biological Chemistry 183:265-275.

Luvizotto Santos, R.; Lee, J. T.; Pereira Branco, Z.; Bianchini, A. \& MAIA NerY, L. E. 2003. Lipids as energy source during salinity acclimation in the euryhaline crab Chasmaganthus granulata Dana, 1851 (Crustacea-Grapsisdae). Journal of Exerimental Zoology 295A:200-205.

Martins, T. L.; Chittó, A. L. F.; Rossetti, C. L.; Brondani, C. K.; KuCharsKi, L. C. \& Da Silva, R. S. M. 2011. Effects of hypoor hyperosmotic stress on lipid synthesis and gluconeogenic activity in tissues of the crab Neohelice granulata. Comparative Biochemistry and Physiology 158A:400-405.

Meade, M. E.; Doeller, J. E.; Kraus, D. W. \& Watts, S. A. 2002. Effects of temperature and salinity on weight gain, oxygen consumption rate, and growth efficiency in juvenile red-claw crayfish Cherax quadricarinatus. Journal of World Aquaculture Society 33:188-198.

MykLes, D. L. 2011. Ecdysteroid metabolism in crustaceans. Journal of Steroid Biochemistry and Molecular Biology 127:196-203.

Paul, R. J.; Lamkemeyer, T.; Maurer, J.; Pinkhaus, O.; Pirow, R.; Seidl, M. \& ZeIS, B. 2004. Thermal acclimation in the microcrustacean Daphnia: a survey of behavioural, physiological and biochemical mechanisms. Journal of Thermal Biology 29:655-662.

Sánchez Paz, A.; Garcia-Carreño, F.; Muhlia-Almazanb, A.; Peregrino-Uriarte, A.; Hernandez-Lopez, J. \& YepizPlascencia, G. 2006. Usage of energy reserves in crustaceans during starvation: Status and future directions. Insect Biochemistry and Molecular Biology 36:241-249.

SoKal, R. R. \& Rohlf, F. J. 1981. Biometry. The Principles and Practice of Statistics in Biological Research. 2ed. New York, W H. Freeman. 832p.

Stoner, A. W.; Ottmar, M. L. \& Copeman, L. A. 2010. Temperature effects on the molting, growth, and lipid composition of newlysettled red king crab. Journal of Experimental Marine Biology and Ecology 393:138-147. 
Tian, X.; Dong, S.; Wang, F. \& Wu, L. 2004. The effects of temperature changes on the oxygen consumption of juvenile chinese shrimp Fenneropenaeus chinensis (Osbeck). Journal of Experimental Marine Biology and Ecology 310:59-72.

VAN HANDEL, E. 1965. Estimation of glycogen in small amount soft tissue. Analytical Biochemistry 11:256-265.

Vinagre, A. S. \& DA Silva, R. S. M. 1992. Effects of starvation on the carbohydrate and lipid metabolism in crabs previously maintained on a high protein or carbohydrate diet. Comparative Biochemistry and Physiology 102A:579-583.
Yudkovski, Y.; Shechter, A.; Chalifa-Caspi, V.; Auslander, M.; Ophir, R.; Dauphin-Villemant, C.; Waterman, M.; SAGI, A. \& Tom, M. 2007. Hepatopancreatic multi-transcript expression patterns in the crayfish Cherax quadricarinatus during the moult cycle. Insect Molecular Biology 16:661674.

Zhou, M.; Wang, A. L. \& Xian, J. A. 2011. Variation of free amino acid and carbohydrate concentrations in white shrimp, Litopenaeus vannamei: Effects of continuous cold stress. Aquaculture 317:182-186. 